\title{
Analyzing the Brand Equity and Resonance of Banking Services: Malaysian Consumer Perspective
}

\author{
Norzalita Abd Aziz (Corresponding author) \& Norjaya Mohd Yasin \\ Graduate School of Business, Universiti Kebangsaan Malaysia, 43650 Bangi, Malaysia \\ Tel: 60-3-8921-3798Ｅ-mail: eita@ukm.com
}

\begin{abstract}
This study attempts to verify the determinants of brand equity of services based on consumers' perception of a banking service. The conceptual framework of this study is based on customer-based brand equity called the Brand Resonance model, which comprises six building blocks, namely, brand salience, brand performance, brand imagery, brand judgment, brand feelings and brand resonance. Factor analyses were conducted on all items measuring the six constructs and the results produced only five factors i.e. brand salience, brand performance, brand judgments, brand feelings and brand resonance as the determinants of brand equity of services. The reliability test on all these factors produced satisfactory reliability coefficients. Correlation analysis was also conducted on the study variables and the results indicate that there are strong, positive and significant relationships between brand performance and brand judgment, and between brand performance and brand feelings. Strong, positive and significant relationships are also found between brand performance and brand resonance, between brand judgment and brand resonance as well as between brand feelings and brand resonance. The multiple regression results show that only Brand Feelings, Brand Judgments and Brand Performance 1 have a significant influence on Brand Resonance.
\end{abstract}

Keywords: Brand resonance, Brand equity, Banking services, Consumer

\section{Background of study}

Recent writings on brand equity indicate that brand equity is the current marketing focus of many leading companies today. The usefulness of brand equity in the business world is undeniably important. It is not only important to businesses that offer tangible products but also to service organizations. Recent trends in marketing are creating global brands that compete across countries and cultures. With the efforts of many companies to have their service brands become more internationally recognized it is increasingly important to understand service brand equity and to become more sophisticated in managing services.

Although branding is often associated with tangible goods, it is just as relevant for intangible goods such as services. With tangible goods, the physical product is the primary brand. For services, the service organization or the service provider is the primary brand. There are fundamental differences between goods and services, which may have implications for brand equity. For example, the branding efforts for tangible products can be materialized through the product, packaging, labelling, and logo design. On the other hand, services lack the tangibility that allows packaging, labelling and displaying. Services are less standardized and are composed largely of abstract experience attributes, the value of which must be inferred by the consumer (Cobb-Walgren, Ruble \& Donthu, 1995). Brand equity has emerged as one of the crucial issues to be discussed and understood in marketing (Keller, 1993, Aaker, 1996, Dyson et al., 1996, Kim and Kim, 2005). Moreover, it has been discussed in a number of different ways and for various purposes (Keller, 2003; Atilgan et al', 2005).

According to Berry (2000), branding is a principal success driver for service organizations. Brand development is important in services because of the difficulty in differentiating products that lack physical differences (Zeithalm, 1981). Furthermore, the intense competition in the service markets also makes service branding very relevant. Branding plays a special role in services because strong brands increase customers' trust of the invisible purchase (Berry, 2000). It offers an opportunity for consumers to establish a mental picture of the service. Strong service brands enable customers to better visualize and understand intangible products. Understanding brand equity in the marketing context is considered an attempt to define the relationship between customers and brands (Wood, 2000). Many service industries, such as financial services or telecommunications, are facing increasing competition, which makes it more important for the service provider to establish a strong brand, not only in the market but also in the minds of the customer (Bamert \& Wehrli, 2005, Kellar, 2003). Strong brand is an important relational tool (Erdem and Swait ,1998) and valuable to consumers because i) it reduces perceived risk of consumption and ii) economize decision-making costs (Stigler, 1961; Stiglitz, 1987). In addition, Berry (2000) 
indicates that it is important to understand that in the context of services, the primary service brand and the organisation are often synonymous.

The primary goal of this study is to gain an understanding of the formation of service brand equity from the perspective of the consumer. To accomplish this goal, the brand equity of service in the banking industry is examined. The main objective of this study is to empirically test a conceptual model of brand equity that investigates the factors involved in building a strong brand based on the Brand Resonance Model as proposed by Keller (2001). Specifically, this study focuses on the following objectives:

1. To verify the determinants of brand equity of services

2. To determine the relationship between the components of brand equity

3. To examine the extent that Brand Feelings, Brand Judgments, Brand Performance and Brand Salience account for the variance in Brand Resonance.

\section{Brand equity and resonance}

The key to brand management and development is to understand what benefits consumers are looking for. As consumers today are more demanding, they are not just looking for functional benefits but they are also looking for intangible benefits such as image, status, personality, lifestyle, success and other factors that they can strongly relate to. Therefore, what consumers are looking for is a list of attributes, which go beyond the physical and tangible aspects of a product. This added value or the incremental utility of the product that comes with the brand name is termed brand equity.

The issue of brand equity has emerged as one of the most critical areas for marketing and management since the 1990s. The term brand equity has been referred to as the tremendous value that the brand name brings to the producers, retailers and consumers of the brand. Brand equity appears where consumers willingly pay more for the same level of quality due to the attractiveness of the name attached to the product (Bello \& Holbrook, 1995). In the marketing literature, brand equity is referred to as the intangible brand properties. Brand equity arose from customer brand-name awareness, brand loyalty, perceived brand quality and favourable brand symbolisms and associations that provide a platform for a competitive advantage and future earning streams (Aaker, 1991). The equity that a strong brand possesses can give the company a loyal consumer franchise that could bring substantial returns to the firm.

The importance of brand equity in services can be looked at from the perspective of the service provider and the consumer. To the service organization brand equity gives a differential advantage that enables the firm to generate greater profits including greater customer loyalty and also protects the firm's offerings from competitive attacks (Berry, 2000). In addition, brand equity creates a more favourable consumer response to price increases and decreases, greater trade and increased marketing communication effectiveness and brand extension opportunities. The differentiation that results from brand equity will lead to a competitive advantage that is based on non-price competition (Aaker, 1991). Furthermore, brand equity contributes to the overall image of the service provider by building traffic and ensures consistent sales volume.

However, all the benefits of brand equity are not meaningful if the service has no meaning to the consumer. In other words, there is value to the service organization, only if there is value to the consumer. A service can only be of value to consumers if it gives satisfaction to them. Customer satisfaction can only come from an efficient and effective service offering. Thus, it is important to understand how the service brand value is created in the minds of the consumers and how this value is translated into consumer behaviour such as purchase and choice decision and ultimately brand loyalty. Several writings have discussed the importance of brand equity and how to build and manage brand equity. Among them are those found in well-known books written by Aaker (1991), Kapferer (1995), Aaker (1996) and Keller (1998). The theoretical and practical implications of brand equity have been explored by a proliferation of research literature in marketing (e.g. Aaker, 1996; Kamakura \& Russell, 1991; Keller, 1993; Simon \& Sullivan, 1993). Brand is considered as a defensive marketing tool in the retail service context in order to retain current customers and gain new customers (Rust e al., 1995; Heskett et al., 1994).

For many years, brand equity has been a topic of interest in consumer goods market, particularly the fast-moving consumer goods. In the consumer goods market, customer service can be considered as a marketing instrument, but in the services market customer service is part of the perceived quality of a service (Bamert \& Wehrli, 2005). According to Berry (1986), a key to success in services marketing is to "tangibilize the intangible" and one way to increase the tangible nature of a service is to use an extrinsic cue like a brand. Services brands help to reduce the risk in consumers' purchase as well as consumption. In addition, brands also help to optimize their cognitive processing abilities and economize decision-making costs (Onkvisit \& Shaw, 198; Stiglitz, 1987). The brand can 
be described as a mechanism to engage the buyer and the seller in a long-term relationship and play a key role in building this relationship based on the customers' experience (Davis et al., 2000; Brodie et al., 2002; Erdem and Swait, 1998).

\section{Theoretical model}

Brand equity is a multi-dimensional concept and a complex phenomenon. Several authors have proposed various models of brand equity and some of the established brand equity models are the Aaker Model (Aaker 1991); Customer-based Brand Equity (CBBE) model and the Brand Resonance model (Keller 2001); Brand Asset valuator by Advertising Agency Young and Rubicam; and the BRANDZ model of brand strength by marketing research consultant Millward Brown and WPP (as quoted in Kotler \& Keller, 2006). Among the most commonly cited are the Aaker Model and the CBBE model. Studies that empirically test the proposed constructs in the other models, such as the Brand Resonance model, are rather limited.

The theoretical framework for this study is based on the consumer based brand equity model called the Brand Resonance model developed by Keller (2001). Keller proposed four main constructs, namely, brand identity, brand meaning, brand responses and brand relationships. These four constructs consist of six "brand building blocks", which he assembled as a brand pyramid (refer Fig. 1). The basic premise of the model is that the power of a brand lies in what customers learnt, felt, saw and heard about the brand over time (Keller, 2001). The creation of brand equity involves reaching the top of the brand pyramid. According to Keller (2001), the six building blocks are: (1) Brand salience, which relates to how often the brand is evoked in purchasing and consumption situations, (2) Brand performance, the extent to which the product meets customers' functional needs, (3) Brand imagery, which relates to the extrinsic properties of the product, (4) Brand judgments, which focus on customers' personal opinions and evaluations, (5) Brand feelings that are customers' emotional responses and reactions towards the brand, and (6) Brand resonance, which refers to the nature of the customer-brand relationship and the extent to which customers feel that they are "in sync" with the brand (Keller, 2001; Kotler \& Keller, 2006).

In building a strong brand the first step is to ensure identification of the brand with customers. This is called brand salience, which relates to aspects of customer awareness of the brand. The second step is to establish the brand meaning in the minds of customers, which involves establishing a brand image. Brand meaning is made up of two major categories of brand associations that exist in the customers' mind, that is, performance and imagery. The third step is to elicit the proper customer responses in terms of their judgments and feelings concerning regard the brand. The fourth and final step is to convert brand response to create an intense, active loyal relationship between the customers and the brand. This is termed as brand resonance, which focuses upon the ultimate relationship and level of identification that customers have with the brand (Keller 2001). In the Brand Resonance model, customers with true brand resonance, have a high degree of loyalty and actively seek means to interact with the brand and share their experiences with others (Atilgan, Aksoy \& Akinci, 2005)

\section{Methodology}

For the purpose of this study, the services offered by the private sector will be examined by focusing only on banking services of commercial banks in Malaysia. The Klang Valley, which is located within the state of Selangor and Federal Territory, is chosen as the sampling area. Being the most modern and advanced region economically and socially, the Klang Valley is the most densely populated region in Malaysia. Thus, a heterogeneous sample that constitutes people from all ethnic groups and various demographic characteristics can be drawn from these areas. The table for determining the sample size from a given population with the desired accuracy, as suggested by Reeves (1992), is used as a reference for sample size. The population of consumers being considered in this study are those household members that are employed in organizations and are holding positions in the professional, administrative and managerial, technical, clerical, sales and service areas. Based on the Malaysian Statistics Department Report 1991, the population size for the eligible respondents in the Klang Valley is huge. From the table suggested by Reeves (1992), the required sample size for a population of 500,000 and above is 399 at $95 \%$ confidence level. Therefore, the required sample size for this study is 399 .

This study employs cluster sampling, a type of probability sampling, which involves the division of the sampling area into regions. From each of these regions a probability sample of organizations was chosen where the final sample was then drawn from the employees of these organizations. A self-administered structured questionnaire was developed to collect quantitative data pertaining to the six building blocks of brand equity. A survey was conducted among consumers through self-administered questionnaires, which were distributed to the adult members of the population who have had service encounters with various commercial banks in Malaysia. All variables were measured based on the consumers' perception and the measurements for the six constructs 
proposed by Keller (2001) were adopted and adapted. Some self-constructed measurements were also included.

\section{Findings}

\subsection{Respondents' Profile}

A total of 480 usable questionnaires were gathered and analyzed. The characteristics of the sample are shown in Table I.

\subsection{Statistical Analysis}

\subsubsection{Exploratory Factor Analysis}

For each of the item scales, factor analysis was used to reduce the total number of items to a smaller number of underlying factors. Principal components analysis was used to extract factors (eigenvalues $>1$ ). Varimax rotation was used to facilitate the interpretation of the factor matrix. The Bartlett's Test of Sphericity and the Kaiser-Meyer-Olkin measure of sampling adequacy were used to validate the use of factor analysis. Exploratory factor analyses were conducted on the various constructs, namely, brand salience (5 items), brand performance (14 items) brand imagery (4 items), brand judgment (19 items), brand feelings (5 items) and brand resonance (17 items). The convergent and discriminant validity of the constructs were tested by principal components analysis. The KMO index for all the analyses was found to be greater than 0.80 , which indicates the presence of sufficient intercorrelations in the data matrix and the appropriateness of factor analysis.

In order to test the reliability of the scales and each of the brand equity constructs, Cronbach's alpha scores were evaluated. The factor analysis for the construct brand identity that measures brand salience produced only one factor with an eigenvalue of 4.34 , contributing $86.81 \%$ to item variance. The factor analysis for brand meaning produced four factors with eigenvalues greater than 1 , contributing $56.11 \%$ to item variance. However, only the first two factors, BP1 and BP2, have an acceptable reliability of 0.875 and 0.886 , respectively. The factor for brand imagery does not have an acceptable reliability so this variable was dropped from subsequent analysis. Factor analysis on brand responses produced six factors with an eigenvalue greater than 1, contributing $65.06 \%$ to item variance, but only the first two factors, namely, brand judgments and brand feelings have acceptable reliability. Factor analysis on variable brand resonance produced five factors with eigenvalues more than one, contributing to $57.38 \%$ of item variance. However, only the first factor has an acceptable reliability that is, 0.90 . The results of factor analyses are shown in Table 2.

\subsubsection{Correlation Analysis}

The means and standard deviations of the study variables are shown in Table 3. Pearson correlation was performed to obtain an understanding of the relationship between all the variables in the study. The values of the correlation coefficients given in Table V reflect the degree of association between each of these variables. From Table 4, it is evident that there is a strong, significant and positive correlation between brand performance and brand judgment $(r=0.79)$ at a significance level of 0.01 . There is also a strong, significant and positive correlation between brand performance and brand resonance $(r=0.63)$ at a significance level of 0.01 and between brand performance and brand feelings $(\mathrm{r}=0.59)$. Correlation is also strong, significant and positive $(\mathrm{r}=$ 0.71 ) at a significance level of 0.01 for brand judgment and brand resonance, and also between brand resonance and brand feelings $(r=0.74)$. The correlations between some of the variables are weak, for example, between brand performance and brand judgments $(\mathrm{r}=0.154)$, between brand performance 2 and brand feelings $(\mathrm{r}=0.14)$, and between brand performance 2 and brand resonance $(\mathrm{r}=0.18)$.

\subsubsection{Regression Analysis}

This model as shown in Table 5, explains 62.9 percent of the variance in Brand Resonance among respondents and, thus, about 36 percent of differences, which indicates that other factors might have an effect on the Brand Resonance among the respondents. Furthermore, the model shows that only Brand Feelings, Brand Judgments and Brand Performance 1 have a significant relationship with Brand Resonance. The results show that the intercept $\mathrm{a}=-0.387$ and the partial regression coefficient values are $\mathrm{b} 1=0.525, \mathrm{~b} 2=0.344, \mathrm{~b} 3=0.135$.

Thus, the estimated regression equation on the predicted model is:

Brand Resonance $=-0.387+0.525$ Brand Feelings +0.344 Brand Judgments +0.135 Brand Performance 1+ 0.008 Brand Performance $2+0.000$ Brand Salience. Moreover, with the largest absolute value of standardized beta coefficient $(\beta=0.470)$, Brand Feelings emerged as the most important predictor or determinant of Brand Resonance, followed by Brand Judgments $(\beta=0.278)$ and Brand Performance $1(\beta=0.119)$. The plausible 
explanation is that the more positive or higher the Brand Feelings, the more positive or higher the Brand Resonance among the respondents.

\section{Discussion}

From the results of factor analyses on the constructs of brand equity, as proposed in the Brand Resonance Model by Keller (2001), it is evident that only five factors are relevant in building brand equity of services, particularly the banking service. These five factors, which form the determinants of service equity are brand salience, brand performance, brand judgment, brand feelings and brand resonance. Among these variables, brand performance is strongly related to brand judgment, brand feelings and brand resonance. Similarly, brand judgment is also strongly related to brand feelings and brand resonance. There is also a strong relationship between brand feelings and brand resonance.

The creation of significant Brand Equity requires a company to achieve the pinnacle of the brand pyramid (Kotler, 2006). As explained previously, Brand Resonance refers to the nature of the relationship customers will have with the brand, while Brand Feelings relate to customers' emotional responses and reactions towards the brand. Brand Feelings are involved with the intrinsic value that the customers have towards the service provided. This is the most important factor that influences the relationship building between the company and customer Brand Resonance involving feelings of self respect, security, social approval and excitement. Brand judgments focus on customers' own personal opinions that relate to customers' trust, experience and perception after receiving the service. Brand Performance is related to how well the product or service meets the customers' functional needs. It is related to functional activities of bank usage such as how to satisfy basic banking needs.

The findings related to the suggestions developed by Gronroos (2001). Gronroos proposed several criteria of good service quality that include the technical and functional aspects of services, which integrate with studies such as SERVQUAL developed by Parasuraman et al. (1998). Thus, a service organization such as a financial company should realize that:

- Its employees, operational systems and physical resources have the knowledge and skills to serve customers and solve their problems in a professional way.

- Reliability and Trustworthiness show that customers can rely on the service provider its employees and systems.

- Service recovery takes places as soon as something goes wrong or something unpredictable happens. Financial service organizations such as banks should actively take action to control the situation and find an acceptable solution.

- Attitudes and Behaviour show a customer that the frontline staff or contact person are concerned about them.

- Reputation and Credibility mean that the service provider's business can be trusted and gives adequate value.

- Accessibility and Flexibility mean that the service organization is easy to reach and is prepared to adjust its demands. This involves functional quality, which is based on how the service is delivered.

In order to develop the relationship between company and customer - Brand Resonance, the extrinsic value is not as important as the intrinsic value such as Brand Feelings and Judgments. In the service industry, the fundamental difference is the intangibility and service experience. Therefore, the technical and functional service quality cannot be separated and happens simultaneously. Brand Feelings, Brand Judgments and Brand Performance 1 (Functional aspect) are found to be important factors that help to build Brand Resonance. The influence of these dimensions leads to the formation of customer relationship, which, in turn, will contribute to the formation of brand loyalty. This study's findings are consistent with Brodie et al (2002) and Davis et al. (2000), which strengthens the concept that the brand takes a wider meaning in the context of services. In the context of relational services, the focus of the brand is on the customer's experience with the organization and how this establishes brand perceptions and meaning.

The approach of this study is based on the customers' view and Kellar (2003) has identified the term customer-based brand equity (CBBE). This approach shows that that the power of the brand lies in what customers have learnt, felt, saw and heard about it over time. Trustworthiness (believability) and expertise (perceived ability) of the brand is to deliver what is promised. Therefore, financial service providers should recognize that customers can have a relationship with the brand and the brand communicates with the customers. In financial services the functional quality cannot be considered detached from the technical quality, as stated by 
Gronroos (2001), "What the customer receives" always depends on "How the customer receives it". Customer service is an important part in consumer markets because it enriches a service in different ways and influences brand resonance. In the service industry customer service is a part of the perceived quality, thus it stands for the function quality. Thus, in order for the financial service provider to achieve brand resonance and brand equity, they need to integrate the perspective of the customer - what is the customer trying to accomplish, for the employee - what are employees doing to provide the service and how is the service produced. It should include a detailed study of internal operations; map out how the company responds to customers' needs and describe how the company uses that information to improve their brand resonance. An effective way to delight customers and maintain their patronage is to offer individualized rewards to different groups of customers such as to increase social-relational rewards and reward consumer with a special privileged group. In addition, the financial service organization can provide informational rewards, such as including personalized advice or information about certain services and provide functional rewards like reducing the time spent in the banking hall, etc.

The content of the present study focuses on retail banks with which the average consumer has a long-term relationship. The results may differ in other service contexts such as hotels, travel agents, etc. The generalization of the current results should be further researched in the future. In addition, the cross-sectional design is also a limitation of the research, there is a need for longitudinal studies to further understand the relationship between constructs in this study that will change over time. Sweeney and Swait (2008) suggested that the brand should be clear in its focus and what it stands for, as well as reveal the culture of the organisation. The brand of service firm should be consistent in its marketing mix decisions (service quality, pricing, promotion, channel), including communication with the customer.

\section{Conclusion}

From this study, the Brand Resonance model, which is a customer-based brand equity model, maintains that building a strong brand involves a series of logical steps as suggested by Keller (2001). That is, establishing brand identity, creating appropriate brand meaning, eliciting the right brand response and forging appropriate brand relationships with customers. It implies that consumer awareness contributes in building the meaning of the brand, which will influence consumer responses towards the brand, which, in turn, will contribute in the establishment of consumer-brand relationship. The importance of this model is that it provides a road map and guidance to marketers in building strong brands. It also implies that marketers must take responsibility to design and implement effective and efficient brand building programmes in order to achieve resonance with their customers. The brand is an important relational tool in the service firms' customer relationship management and brands are valuable to consumers because they reduce the perceived risk of consumption.

\section{References}

Aaker, D.A. (1991). Managing Brand Equity. New York: Macmillan.

Aaker, D.A. (1996). Measuring brand equity across products and markets. California Management Review, 38, 102-120.

Atilgan, E., Safak, A., and Serkan, A. (2005). Determinants of the brand equity. A verification approach in the beverage industry in Turkey. Marketing Intelligence \& Planning, 23, 237-248.

Bamert, T., and Wehrli, H. P. (2005). Service quality as an important dimension of brand equity in Swiss services industries. Managing Service Quality, 15(2), 132-141

Bello, D.C., and Holbrook, M. B. (1995). Does an absence of brand equity generalize across product classes? Journal of Business Research, 34, 125-131.

Berry, L.L. (1986). Big ideas in services marketing. Journal of Services Marketing, 5-9.

Berry, L.L. (2000). Cultivating service brand equity. Journal of the Academy of Marketing Science, 28, 128-37.

Brodie, R.J., Glynn, M.S., and Van Durme, J. (2002). Towards a theory of marketplace equity. Marketing Theory, 2(1), 5-28.

Cacioppo, J.T., \& Petty, R.E. (1979). The effects of message repetition and position on cognitive response, recall, and persuasion. Journal of Personality and Social Psychology, 37, 97-109.

Cobb-Walgren, C.J., Ruble, C.A., and Donthu, N. (1995). Brand equity, brand preference, and purchase intent. Journal of Advertising, XXIV, 25-40.

Davis, R., Buchanan-Oliver, M., and Brodie, R.J. (2000). Retail service branding in electronic -commerce environments. Journal of Service Research, 3(3), 178-186. 
Dyson, P., Farr, A., and Hollis, N.S. (1996). Understanding, measuring and using brand equity. Journal of Advertising Research, 36(6), 9-13.

Erden, T., and Swait, J. (1998). Brand equity as a signaling phenomenon. Journal of Consumer Psychology, 7(2), 131-157.

Farquhar, P.H. (1990). Managing brand equity. Journal of Advertising Research, (Aug/Sept), 7-12.

Gronroos, C. (2001). Service Management and Marketing - A Customer Relationship Management Approach, $2^{\text {nd }}$ Edition, Wiley, Chichester.

Heskett, J.L., Jones, T.O., Loveman, G.W., and Sasser, W.E.J. (1994). Putting the service-profit chain to work. Harvard Business Review, (March-April), 164-174.

Kamakura, W.A., and Russell, G.J. (1993). Measuring brand value with scanner data. International Journal of Research in Marketing, 10, 9-22.

Kapferer, E. (1995). Strategic Brand Management New Approaches To Creating and Evaluating Brand Equity. London.

Keller, K.L. (1993). Conceptualizing, measuring, and managing customer-based brand equity. Journal of Marketing, 57, 1-22.

Keller, K.L. (1998). Strategic Brand Management: Building, Measuring, and Managing Brand Equity. Upper Saddle River, Prentice Hall, New Jersey.

Keller, K.L. (2001). Building customer-based brand equity: a blueprint for creating strong brands. Marketing Science Institute Working Paper Series, 1-107.

Keller, K.L. (2003). Understanding brands, branding and brand equity. Interactive Marketing, 5(1), 7.

Kim, H., and Kim, W. (2005). The relationship between brand equity and firm's performance in luxury hotels and chain restaurants. Tourism Management, 26, 549-560.

Kotler, Phillip, \& Keller, K.L. (2006). Marketing Management, $12^{\text {th }}$ edition, Upper Saddle River, Prentice Hall, New Jersey.

Onkvisit, S., and Shaw, J.J. (1989). Service marketing: image, branding, and competition. Business Horizons, 32(1), 13-18.

Parasuraman, A., Zeithaml, V.A., and Berry, L.L. (1988). SERVQUAL: a multiple-item scale for measuring consumer perceptions of service quality. Journal of Retailing, 64(1), 12-40.

Reeves, C.C. (1992). Quantitative Research for the Behaviour Sciences, John Wiley \& Sons, Inc., New York.

Reicheld, F.F., and Sasser, W.E. (1990). Zero defections: Quality comes to services. Harvard Business Review, (September- October), 105-111.

Rust, R.T., Zahowik, A.J., and Keiningham, T.L. (1995). Return on quality (ROQ): Making service quality financial accountable. Journal of Marketing, 59(April), 58-70.

Simon, C.J., and Sullivan, M. W. (1993). The measurement and determinants of brand equity: a financial approach. Marketing Science, 12, 28-52.

Smith, J.W. (1991). Thinking about brand equity and the analysis of customer transactions. In Managing Brand Equity: A Conference Summary, Report No. 91-110, Eliot Maltz, ed., Cambridge, MA: Marketing Science Institute, 17-18.

Smith, R.E., and Swinyard, W.R. (1983). Attitude-behaviour consistency: the impact of product trial versus advertising. Journal of Marketing Research, 29, 257-267.

Stigler, G.D. (1961). The economics of information. Journal of Political Economy, 69, 13-26.

Stiglitz, J. (1987). The causes and consequences of the dependence of quality on price. Journal of Economic Literature, 25, 1-48.

Sweeney, J., and Swait, J. (2008). The effects of brand credibility on customer loyalty. Journal of Retailing and Consumer Services, 15, 179-193.

Wood, L. (1995). Brands and brand equity: Definition and management. Management Decision, 38.

Yoo, B., Donthu, N., and Lee, S (2000). An examination of selected marketing mix elements and brand equity. Journal of the Academy of Marketing Science, 28, 195-211. 
Zeithalm, V.A. (1981). How consumer evaluation processes differ between goods and services. Marketing of Services. Eds. James H. Donnelly and William R. George. Chicago: American Marketing Association, 186-189

Zeithaml, V.A., Parasuraman, A., and Berry, L.L. (1985). Problems and strategies in services marketing, Journal of Marketing, 49(4), 36-46.

Table 1. Profile of Respondents

\begin{tabular}{|c|c|c|}
\hline Characteristics & Frequency $\quad(N=480)$ & Percentage (\%) \\
\hline \multicolumn{3}{|l|}{ Gender } \\
\hline Male & 199 & 41.5 \\
\hline Female & 281 & 58.5 \\
\hline \multicolumn{3}{|l|}{ Age } \\
\hline $18-22$ & 140 & 29.2 \\
\hline $23-27$ & 114 & 23.8 \\
\hline $28-32$ & 83 & 17.3 \\
\hline $33-37$ & 41 & 8.5 \\
\hline $38-42$ & 42 & 8.8 \\
\hline More than 42 years & 60 & 12.5 \\
\hline \multicolumn{3}{|l|}{ Ethnic group } \\
\hline Malay & 299 & 62.3 \\
\hline Chinese & 123 & 25.6 \\
\hline Indian & 51 & 10.6 \\
\hline Others & 7 & 1.5 \\
\hline \multicolumn{3}{|l|}{ Education } \\
\hline SPM/MCE & 78 & 16.3 \\
\hline $\mathrm{STP} / \mathrm{HSC}$ & 44 & 9.2 \\
\hline Diploma & 70 & 14.6 \\
\hline Bachelor's Degree & 226 & 47.1 \\
\hline Masters/PhD & 46 & 9.6 \\
\hline Others & 16 & 3.3 \\
\hline \multicolumn{3}{|l|}{ Income } \\
\hline 1000 and below & 183 & 38.1 \\
\hline 1001 to 3000 & 210 & 43.8 \\
\hline 3001 to 5000 & 47 & 9.8 \\
\hline 5001 to 7000 & 24 & 5.0 \\
\hline 7001 to 9000 & 8 & 1.7 \\
\hline 9001 to 11,000 & 7 & 1.5 \\
\hline 11,001 and above & 1 & 0.2 \\
\hline
\end{tabular}


Table 2. Exploratory Factor Analysis and Scale Reliability

\begin{tabular}{|c|c|c|c|c|c|}
\hline Items & Loading & TVE & MSA & Signif. & Reliability \\
\hline \multicolumn{6}{|l|}{ Brand Salience } \\
\hline I know the symbol of Bank X looks like & 0.99 & & & & \\
\hline I know the colour that symbolizes Bank X & 0.99 & & & & \\
\hline I can recognize Bank $\mathrm{X}$ among other competing banks & 0.99 & & & & \\
\hline I can quickly recall the symbol/logo of Bank X & 0.99 & 86.81 & 0.898 & 0.00 & 0.92 \\
\hline \multicolumn{6}{|l|}{ Brand Performance 1 (BP1) } \\
\hline \multicolumn{6}{|l|}{$\begin{array}{l}\text { Compared to other commercial banks, Bank } \mathrm{X} \text { gives a better } \\
\text { service }\end{array}$} \\
\hline The services of Bank X are effective & 0.82 & & & & \\
\hline \multicolumn{6}{|l|}{ Compared to other commercial banks, Bank X satisfies my basic } \\
\hline needs & 0.80 & & & & \\
\hline Bank X has special features & 0.80 & & & & \\
\hline It is easy to get services from Bank $\mathrm{X}$ & 0.75 & & & & \\
\hline Bank X uses high technology in its services & 0.66 & & & & 0.88 \\
\hline \multicolumn{6}{|l|}{ Brand Performance 2 (BP2) } \\
\hline $\begin{array}{l}\text { Compared to other commercial banks, the service charge of bank } \\
\mathrm{X} \text { is high }{ }^{\circledR}\end{array}$ & 0.95 & & & & \\
\hline Compared to other commercial banks, the rate of interest of bank & 0.95 & & & & \\
\hline $\mathrm{X}$ is high ${ }^{\circledR}$ & & 56.11 & 0.81 & 0.00 & 0.89 \\
\hline \multicolumn{6}{|l|}{ Brand Judgments } \\
\hline My overall opinion of Bank X is good & 0.84 & & & & \\
\hline I trust Bank X so much & 0.80 & & & & \\
\hline The quality of Bank $\mathrm{X}$ is consistent & 0.80 & & & & \\
\hline I am likely to recommend Bank $X$ to others & 0.78 & & & & \\
\hline Personally, Bank $\mathrm{X}$ is relevant to me & 0.80 & & & & \\
\hline Bank $\mathrm{X}$ is innovative & 0.75 & & & & \\
\hline The staffs of bank $X$ are knowledgeable & 0.69 & 53.37 & 0.89 & .00 & 0.89 \\
\hline \multicolumn{6}{|l|}{ Brand Feelings } \\
\hline Bank X gives me a feeling of self-respect & 0.88 & & & & \\
\hline Bank $X$ gives me a feeling of social approval & 0.86 & & & & \\
\hline Bank X gives me a feeling of excitement & 0.82 & & & & \\
\hline Bank X gives me a feeling of security & 0.79 & 71.26 & 0.84 & .00 & 0.86 \\
\hline \multicolumn{6}{|l|}{ Brand Resonance } \\
\hline I really love Bank $\mathrm{X}$ & 0.85 & & & & \\
\hline Bank $\mathrm{X}$ is the one bank that I prefer & 0.81 & & & & \\
\hline I feel Bank X is the only bank that I need & 0.80 & & & & \\
\hline \multicolumn{6}{|l|}{ I am proud to have others know that I am a customer of Bank X } \\
\hline I consider myself loyal to Bank X & 0.78 & & & & \\
\hline $\begin{array}{l}\text { I feel like I almost belong to a club with other customers of Bank } \\
\mathrm{X}\end{array}$ & 0.77 & & & & \\
\hline \multirow[t]{2}{*}{ I am always interested in learning more about Bank X } & 0.77 & & & & \\
\hline & 0.74 & 57.38 & 0.88 & .00 & 0.90 \\
\hline
\end{tabular}

$T V E=$ Total Variance Explained; MSA = Measure of Sampling Adequacy

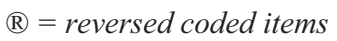


Table 3. Mean and Standard Deviation for Study Variables

\begin{tabular}{|l|l|l|}
\hline Variables & Mean & Standard Deviation \\
\hline Brand Salience & 4.53 & 4.38 \\
Brand Performance 1 & 3.76 & 0.67 \\
Brand Performance 2 & 3.68 & 4.45 \\
Brand Judgments & 3.72 & 0.69 \\
Brand Feelings & 3.48 & 0.69 \\
Brand Resonance & 3.26 & 0.78 \\
\hline
\end{tabular}

Table 4. Pearson Correlation

\begin{tabular}{|l|l|l|l|l|l|l|l|}
\hline & & Salience & Perform1 & Perform2 & Judgment & Feelings & Resonance \\
\hline 1. & Brand Salience & 1.00 & & & & & \\
2. & Brand Performance 1 & .084 & 1.00 & & & & \\
3 & Brand Performance 2 & .018 & $.206^{* *}$ & 1.00 & & & \\
4 & Brand Judgments & .079 & $.786^{* *}$ & $.154^{* *}$ & 1.00 & & \\
5. & Brand Feelings & .027 & $.592^{* *}$ & $.142^{* *}$ & $.699^{* *}$ & 1.00 & \\
6 & Brand Resonance & .047 & $.626^{* *}$ & $.183^{* *}$ & $.708^{* *}$ & $.742^{* *}$ & 1.00 \\
\hline
\end{tabular}

** Correlation is significant at 0.01 levels (2-tailed)

Table 5. The Influence of Brand Feelings, Brand Judgements, Brand Performance $1 \& 2$ and Brand Salience on Brand Resonance

\begin{tabular}{|l|l|l|l|l|}
\hline \multicolumn{1}{|c|}{ Independent Variables } & Unstd. Beta & \multicolumn{1}{c|}{ Std. Beta } & \multicolumn{1}{c|}{ t } & Sig. Value \\
\hline Constant & -0.387 & & & \\
\hline Brand Salience & 0.000 & 0.002 & 0.068 & 0.946 \\
\hline Brand Performance 1 & 0.135 & 0.119 & 2.586 & 0.010 \\
\hline Brand Performance 2 & 0.008 & 0.049 & 1.707 & 0.088 \\
\hline Brand Judgments & 0.344 & 0.278 & 5.422 & 0.000 \\
\hline Brand Feelings & 0.525 & 0.470 & 11.949 & 0.000 \\
\hline $\mathrm{R}=0.793, \mathrm{R}$ Square $=0.629$, Adjusted R Squared $=0.625, \mathrm{~F}=160.912, \quad$ Sig. $\mathrm{F}=0.000$ & & \\
\hline
\end{tabular}

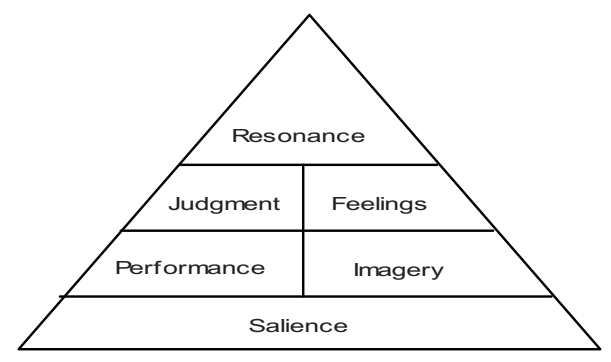

Figure. 1. The Brand Resonance Model 